\title{
Entrepreneurship Development and its Impact on Small Scale Business Enterprises in Developing Countries: A Nigerian Experience
}

Chukwuemeka Nnadi*

Department of Management, Faculty of Business Administration, University of Nigeria, Enugu Campus, Enugu State, Nigeria

\begin{abstract}
Entrepreneurship development and its impact on SMEs in developing countries; the study sets out to accomplish the objectives which were to: ascertain why Nigerian government ignored the human capital development of its citizens find out why Nigerian government silent on the misuse of public funds appropriated development of SMEs. The study used secondary sources. The findings were that: refusal to develop its citizens yielded huge idle fund. Section 308 of 1999 CFRN empowers the President or Vice President, Governor or Deputy Governor misuse it without consequence in law in Section 65 of 1999 CFRN-"up to at least school certificate or its equivalent" mediocre members of the National Assembly. Based on these findings the following recommendations were made that: Nigerian should be transformed into literate citizens to enable them become innovative entrepreneurs. The educational standard -for membership of National Assembly of Nigeria should read a good degree from a recognized university to qualify them as effective participants in global politics and economy. Every Nigerian in official or personal capacity should live under the Rule of Law.
\end{abstract}

Keywords: Entrepreneurs; Unpreparedness; Funding; SMEs; Failure; Government; Indifference; Population; Illiteracy; Dominant

\section{Introduction}

The developed economies have brought the small-scale business enterprises to the front burners of their national development at the critical phase of their respective developments [1]. The stable political situation in these countries and their greater receptiveness to change are factors that favored the SMES growth and development. The policies and actions of their governments and their peoples were centered on the real sectors of agriculture and manufacturing whose development and growth were necessarily anchored on their small and medium scale enterprises- the SMES [2]. The strong political foundation of these advanced nations was (and is) made up of political players, system, process and structures that are grounded in inclusivity and accountability. Also, the active participation of their citizens who seed to restore their individual and collective dignity in the politics of their nation is what ensures that THE PEOPLE will set the agenda and determine the quality and substances of governance [1]. The peopleoriented governments identify common critical growth drivers-human resource/entrepreneur, job creation and security, social and physical infrastructure, investment climate and sector reforms as relevant to the growth and development of their economies. Two of these identified drivers-Job creation and security-are particularly congruent with the development of the SMES. This excluded human resource and entrepreneurs because human capital development is the top priority of governments in advanced countries. The above shows that the health and viability of the SMES was the capstone on which the transformation of these advanced economies was based. The Economic commission for Europe (ECE) [3], reports that the number of enterprises in the non-primary private sector has grown to over 19 million in the European Economic Area and Switzerland, Providing employment for enterprises is classified as small and medium sized enterprises (SMES). The 5 million SMES in the countries of the Central European Initiative (CEI) have more than 25 million employees. The united states have over 22 million small businesses that employ 53 percent of the private workforce and account for ever half of the national economic output. These achievements result from sound planning by their governments and coordinated implementation by knowledgeable and diligent industrious entrepreneurs. Their governments helped in creating enabling environments for SMES so that can more easily cope with the over-increasing challenges. For examples SMES find it harder than larger businesses to find and use the information and advice they need. Also, the burden of regulation is particularly heavy for them. They prepared their entrepreneurs to acquire knowledge and to be able to use the results of innovations and new information. To address this situation government did additional work in a number of areas particularly in the area of business advisory counseling and information services. This seems to be the most effective means of assisting entrepreneurs in improving the competitiveness of small business [4]. Business services help the SMES sector realize its potential contribution to innovation and growth. The European commission affirms that some of the most dynamic SMEs use business services to perform functions that cannot be taken in-house.

Successive Nigeria governments have missed the mark as well as the thrust in the application of her potential for progress and poverty alleviation by rely in her ability to pick mineral from the ground or seek debt belief and foreign assistance they invest more on things than on information and more on the military than on education ignoring knowledge and ideas which are the engine that drive national economic growth. Nigerians squander their wealth like infants who do not know the value of things. These governments have initiated only funding programmes to unprepared entrepreneurs who are parasitic and renowned for encouraging and rewarding conformance to existing standards of performance and behavior cloning most of their employees into replicas of their predecessors in the name of continuity and preservation business culture [5]. All or most of the initiatives

${ }^{*}$ Corresponding author: Chukwuemeka Nnadi, Department of Management Faculty of Business Administration, University of Nigeria, Enugu Campus, Enugu State, Nigeria, Tel: 08066707488; E-mail: chukwuemeka.nnadi@unn.edu.ng

Receved July 18, 2014; Accepted August 04, 2014; Published August 14, 2014

Citation: Nnadi C (2014) Entrepreneurship Development and its Impact on Small Scale Business Enterprises in Developing Countries: A Nigerian Experience. J Entrepren Organiz Manag 3: 119 doi: 10.4172/2169-026X.1000119

Copyright: (c) 2014 Nnadi C. This is an open-access article distributed under the terms of the Creative Commons Attribution License, which permits unrestricted use, distribution, and reproduction in any medium, provided the original author and source are credited. 
of the past failed because of the poor financial management culture and incompetence of most Nigerian SMES other factors manifest in a variety of disabling problems such as absence of basic managerial skills, inappropriate marketing strategies, poor recruitment polices, lack of innovation and access to relevant technology, diversion and misapplication of fund and aversion to ownership dilution [2] since 1960, Nigerian has been suffering from so many epileptic economic policies and situations that have left it a grossly underdeveloped country instead of the economic and political giant of Africa which its funding fathers intended it to be [6]. The Federal Government of Nigerian admitted of its incapacity to actually transform Nigeria into greatness- "Granted political stability, good governance and exemplary leadership, Nigerian has a high potential of becoming a great nation in the $21^{\text {st }}$ millennium" [7]. This is a sincere admission because every government is the exact symbol of its people [8]. The laws and legal system of a society reflect the values of its people [8]. This is expected because the qualifications for election into the National Assembly Section 65(2) states:

"A person shall be qualified for election under subsection 1 of this section if

(a) he has been educated up to at least school certificate level or its equivalent and

(b) he is a member of a political party and is sponsored by that party"

To get out of this economic and development quagmire Nigeria requires policy makers and experts whose education and experience are both broad and deep with sound knowledge of the global economy and who have the requisite skills for identifying and exploiting opportunities, fostering team-based innovation or intercreativity and managing change.

\section{Statement of Problem}

- The time-serving dead phrase- 'As And When Practicable' in section 18(3abc) of 1999 CFRN frustrated the effort of Nigeria to aggressively invest in education of its people thus creating 'nation' of unprepared and complaint entrepreneurs helplessly dependent of government to find their destiny.

- The funding programmes initiated by successive Nigerian failed without any action on the part government officials to investigate and prosecute the offenders.

\section{Objectives of the study}

- To ascertain why Nigerian government failed to pursue the programme of the human capital development of its citizens and its entrepreneurs.

- To find out why Nigerian government showed utter indifference on the misuse of public fund directed to the growth and development of SMEs.

\section{Research questions}

- To what extent does the government reliance on the dead phrase - "AS AND WHEN Practicable..." contribute to human capital development of its citizens and Entrepreneurs?

- How does government indifference and deliberate inaction on the misuse of funding programmes contribute to the growth and sustainability of SMEs.

\section{Theoretical Framework}

The theoretical framework is based on both theory of need for achievement $(\mathrm{n} / \mathrm{ACH})$ and the theory of private victory. They are complementary. Firstly, the theory of need-for-achievement is motivational theory. It means the need for achievement, that is, the sense of doing and getting things done which promotes entrepreneurship. The need for achievement is a stable personality characteristics rooted in experience in middle childhood. Variations The $\mathrm{n} / \mathrm{ACH}$ is important in determining economic growth. Because any organized enterprise and every department of its represent groups of individuals working together to achieve goals, the need for achievement is of paramount importance. Variations in $\mathrm{n} / \mathrm{ACH}$ levels were correlated with stories in children's text books and it was found that $\mathrm{n} / \mathrm{ACH}$ was very high in United States of America 80 or 90 years ago. It is the highest in Russia and China now. This stable personality characteristics rooted in experience in middle childhood repositions the countries of the world in the table of relative largest economies when these children attain maturity. For example, the relative positions of nations in the world Largest Economies (GDP in \$billion in 2004 shows United States as the World's Largest Economy. The second was Japan and China was the Sixth. But in 2010, the same China was second to the United States (Table 1 and Figure 1) people with high with a high need-for-achievement have an intense desire

\begin{tabular}{|l|c|c|c|}
\hline Country & GDP & Country & GDP \\
\hline 1. United States & 10.065 & 11. Brazil & 502 \\
\hline 2. Japan & 4,141 & 12. India & 477 \\
\hline 3. Germany & 1,846 & 13. South Korea & 422 \\
\hline 4. United Kingdom & 1,424 & 14. Netherlands & 380 \\
\hline 5. France & 1,309 & 15. Australia & 368 \\
\hline 6. China & 1,159 & 16. Russia & 310 \\
\hline 7. Italy & 1,088 & 17. Taiwan & 282 \\
\hline 8. Canada & 694 & 18. Argentina & 268 \\
\hline 9. Mexico & 617 & 19. Switzerland & 247 \\
\hline 10. Spain & 581 & 20. Belgium & 229 \\
\hline
\end{tabular}

Source: Based on the Economist Pocket World in Figures (World Profile Books 2004) page 24.

Table 1: World's Largest Economies GDP in \$billions, 2004.

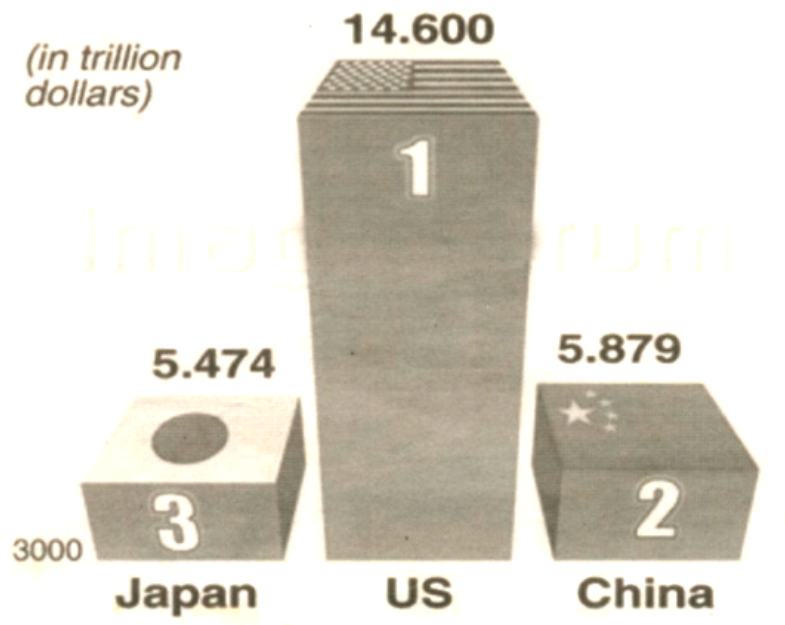

Figure 1: World's Largest Economies (GDP in \$trillions, 2010). Source: Business Day 2011, 2, February 16 Vol 9 No 25 FINANCIAL TIMES. 
for success and an equal fear for failure. This implies that they want to be challenged, set moderately difficult but not impossible goals for themselves, take a realistic approach to risk, they are not likely to be coin tossers' but rather endeavor to analyze and assess problems, prefer to assume personal responsibility to get a job done, they like specific and prompt feedback on how they are doing, also like to work long hours and tend to be restless. They do not worry unduly about failure if it does occur. They tend to like or prefer to run their own shows [9].

\section{List of Countries by GDP (PPP) Per Capital}

This list in Table 2 shows the countries by 2012 GDP (PPP) per capita based on World Bank The World Bank figures were based on actual data. All figures are in current Geary-Khamis dollars, more commonly known as -International dollars (Ints).

The Gross Domestic product at purchasing power party (PPP) per capita for the countries is the value of all final goods and services produced within a country in a given year, divided by the average (or mid year) population for the same year.

Using a PPP basis is arguably more useful when comparing generalized differences in living standards on the whole between nations because PPP takes into account the relative cost of living and the inflation rates of the countries, rather than using just exchange rates which many distort the real difference in income. (Economy World GDP, 2014).

The second is the theory of private victor: [10]. It demands that an entrepreneur be proactive through his visionary objective, begin with the End in mind backed by a positive and unyielding determination at the start-up of the business enterprise (Figure 2) and doing first things first in the sequential structure of the activities in the operations of a business enterprise (Figure 3).

It encourages the use of three principles: (1) a principle of personal vision is the unquestionable ability of man to elevate his life by conscious endeavor [10]. (2) Principles of personal leadership lies within us [10] and (3) Principles of personal management emphasize that things

\begin{tabular}{|c|c|c|c|}
\hline Rank & Country & IntS & Year \\
\hline 9 & Swizerland & 57.705 & 2013 \\
\hline 10 & United States & 53.143 & 2013 \\
\hline 14 & Australia & 43.550 & 2013 \\
\hline 16 & Netherlands & 43.404 & 2013 \\
\hline 17 & Germany & 43.332 & 2013 \\
\hline 19 & Canada & 43.207 & 2013 \\
\hline 21 & Belgium & 40.338 & 2013 \\
\hline 24 & France & 36.907 & 2013 \\
\hline 25 & Japan & 36.315 & 2013 \\
\hline 26 & United Kingdom & 36.209 & 2013 \\
\hline 27 & Italy & 34.303 & 2013 \\
\hline 30 & South Korea & 33.140 & 2013 \\
\hline 32 & Spain & 32.103 & 2013 \\
\hline 43 & Russia & 24.120 & 2013 \\
\hline 67 & Mexico & 16.463 & 2013 \\
\hline 75 & Brazil & 13.024 & 2013 \\
\hline 84 & China & 11.904 & 2013 \\
\hline & Algeria & - & - \\
\hline & Taiwan & - & - \\
\hline & & & \\
\hline & & & \\
\hline & & & \\
\hline & & & \\
\hline & & & \\
\hline & & & 2013 \\
\hline
\end{tabular}

Source: World Development Indicators 2014

Table 2: List of countries.

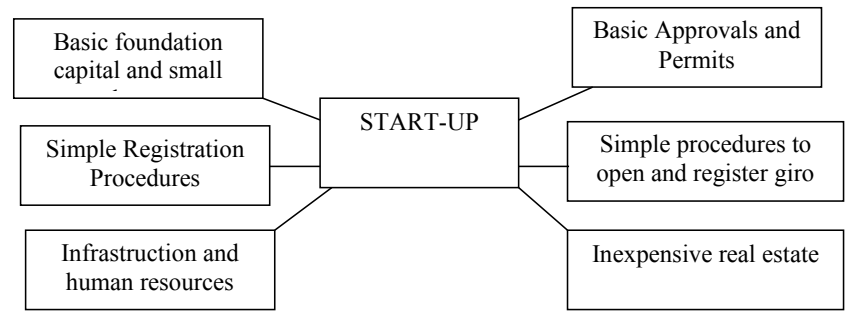

Figure 2: Needs of Start-up.

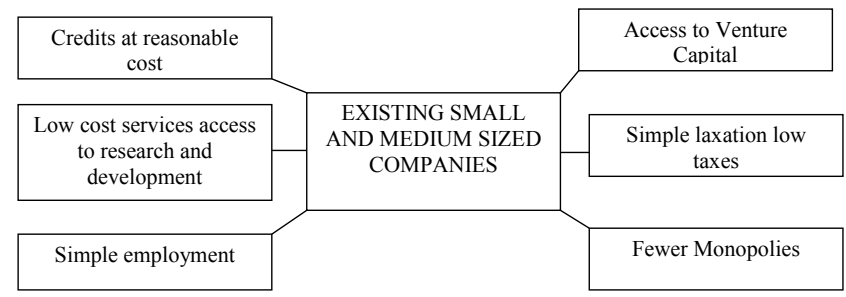

Figure 3: Needs of operational SMES

Source: "Voucher System for Consulting in Slovenia", paper prepared for the UNECE Expert Metting by Mr. Bozidar Marot, Head of Financing and Marketing Division, Small Business Development Centre, Ministry for Small Business and Tourism, Ljubljana, Slovenia.

which matter most must never be at the mercy of things which matter least [10]. Principle Centre: By centering our lives on current principles we create a solid foundation for development of the four-life support factors imagination, consciences, independent will and particularly self-awareness. Principles are deep fundamental truths generic common denominators. Principles do not change our understanding them does. Principles have natural consequences attached to them. It inflames the zeal of the entrepreneur to uncommonly stretch himself and sacrifice greatly his personal endowments and his time to attain highly and achieve great success. The great historian Arnold Toynbee said that you could pretty well summarize the history of society and the institutions in it, in four words. 'Nothing fails like success', in other words when you have a challenge and creative response is equal to or more than the challenge, that is called success or entrepreneurial success [10].

\section{Concept of Small Business Enterprises}

The National Economic Reconstruction Fund (NERFUND) defines small and medium Enterprises as those with total asset value (excluding land) of not more than N10 million. The emphasis of this definition was on initial capital and exclusion land. This implies that accommodation may be rented. Also, the Centre for Management Development (CMD), Lagos in 1974 noted that SME cannot be adequately defined in terms of number of employees, volume of sales, asset employed or a combination of the above because of the inherent misconception that would be embedded in such definition. Hence it concludes into SME cannot be adequately defined. This CMD could not attempt a definition of SME the engine the drives the national economy. This appears to be a centre of political officers not experts in Economic Development. A further definition comes from the National Association of small and medium scale enterprises it states that SME is a business venture that has total assets of less than N150 million and employees less than 100 persons. This is not amenable to empirical verification given the phrase "less than N150 million and employees less than 100". But in Japan the fundamental law of small and medium scale Enterprises defines SME as any business whose capital does not exceed 50 million yen and does 
not employ more than three hundred persons. There is a serious irony: Nigeria's capital out lay is N150 million and it has no place in the World Largest Economics GDP in \$billion 2004 and in GDP in \$trillion, 2010. Ezekwesili [1] describes Nigeria as paradox of the kind of wealth that breeds penury, a poster nation for poor governance wealth from natural resources. The trend of Nigeria's population in poverty since 1980 to 2010 suggest that the more Nigeria earned from oil the larger the population of poor citizens: 17.1 million 1980, 34.5 million in 1985, 39.2 million in 1992, 67.1 million in 1996, 68.7 million in 2004 and 112.47 million in 2010. Yet who in Nigeria has N150 million except the politicians and their relations and business front. Compare this Nigeria's capital outlay of N150 million with modest capital outlay of 50 million yen: Yet Japan was second to United States of America and the World's Largest Economies GDP in \$billion, 2004 and third United States of America and China. With respect to human capital development the government of Japan has undertaken to develop its citizens who possess global skills and can compete everywhere in the world. But Nigerian government in its education objectives section 18(2) Government shall promoted science and technology; 18(3) Government shall strive to eradicate illiteracy 'as and when practible" provide free education (for all). This dead phrase: AS AND WHEN PRACTIBEL" prevents government from performing its fundamental duty: developing its citizens. The idle huge fund arising from deliberate inaction creates the "Immunity Clause" in Section 308 CFRN Empowering the President and this Vice President the Governor and Deputy Governor to use the said in their official capacity anyhow and no law will touch them. This legitimate and wide scale corruption in his places.

\section{National Development}

Harbinson [11] states that country which is unable to develop the skills and knowledge of its people and to utilize them effectively in the national economy will be unable to develop anything else. This because human beings are active agents who accumulate capitals, exploit materials resources build social, economic and political organizations and carry forward national development. Other resources intelligence imagination knowledge land material and equipment though essential resources, they only set limit to what can be done [12]. Sound policies and access for investment in development requires strong political foundation comprising political players, system processes and structures grounded in inclusivity and accountability to achieve development [1]. The active participation of enlightened citizens who seek to restore their individual and collective dignity in the politics of their nation is what ensures that THE PEOPLE will set the agenda and determine the quality and substance of governance [1]. In Nigeria, the reverse is the case. The people are predominantly illiterate with rudimentary knowledge in science and consequently lack the skills to exploit these natural endowments.

\section{SMEs constraints}

Small scale business enterprise in both advanced market economics and in transition economies find it harder than larger business to find and use the information and advice they need. Also, the burden of regulation is particularly heavy for them. In most economics the most significant problems of SMEs include: the transition to the culture of entrepreneurship, the acquisition of business and management skills and technical awareness of the product and service quality demanded by market driven economies. UNECE also recognized that Government can and must help in creating an enabling environment for SME so that they can more easily cope with ever-increasing challenges in addition to the above problems/challenges SMEs face socio-cultural constraints in developing countries.

\section{Socio-cultural constraints}

Nigeria Institute of Management defines the culture as referring to the arts, sculptures and music, values, belief system and interests. A society's culture includes all of the socially leaned and transmitted patterns of behavior, values, customs, morals, tradition, ideas, attitudes which influence individuals and which they share together. The culture of a society moulds each individual from the day he is born until he dies. Drucker confirms that management is a social function embedded in a tradition of values, customs and beliefs and in government and political systems. Management is and should culture bound. The Nigerian managers functions within the Nigerian environment. Nigeria, however, have been described as a Nation where nothing works, the telephone, electricity, water-works, the train the airways and so forth (NIM Study Pack: 24).

\section{Paculial Factors that Impede Growth of SMES}

Entrepreneurship is inhibited by the social system which demes opportunities for creative faculties. The force of custom, the rigidity of status and the distrust of new ideas and of the exercise of intellectual curiosity, combine to create an atmosphere inimical to experiment and innovation.

In less developed countries traditional attitudes discourage the full utilization of human resources.

People are ranked not according to their capacity to do particular jobs but by sex, caste, clan and kinship. Individualistic spirit is absent. People prefer traditional trades and professions rather than venture in new trades. As pointed out by Hagen, villagers and elite alike revere the same economic roles and spurn trade and business, and there is a feeling of repugnance toward work that soils one's hand, in such economies. Thus, 'the value system minimizes the importance of economic incentives, material rewards, independence and rational calculation. It inhibits the development and acceptance of new ideas and objectives .... In short, the cultural value system within many poor countries is not favorable to economic development.

In such economies extreme inequalities in the distribution of income and wealth also stand in the way of the growth of entrepreneurship.

Hardly three to five per cent of the people are at the top of the income pyramid who save. They are mostly traders and landlords who do not like to undertake risks in new business ventures but invest in unproductive channels such as gold, jewellery precious stones, idle inventories luxurious real estates, speculation etc. However, there are some merchants and traders who mostly deal in consumer goods and act as money lenders and real estate agents.

Besides, there exist a few entrepreneurs who are engaged in the manufacture of some consumer goods, and in plantations and mines that tend to become monopolistic and quast-monopolistic. They develop personnel and political contacts with the government official, enjoy a privileged position and receive preferential treatment in financial, taxation, exports, imports etc. Like the South African, government which crested a nation of compliant individuals who depended on the government to control their destiny. The white minority was protected by the government through reserved employment opportunities and laws that prevented black people from participating fully in the economy [5]. It is they who start new industries and thus, found individual business empires, such as the Tatas, Birlas, and the Dalmias in India: Dangote in Nigeria such big business houses inhibit the growth of fresh entrepreneurship within their respective countries. The thin supply of 
entrepreneurs in less developed countries is also attributed to the lack of infrastructural facilities which add to the risk and uncertainty of new entrepreneurship. For example, the indirect costs of doing business are relatively high. It is estimated that the manufacturing sector has to bear additionally indirect costs amounting to 16 percent of sales arising from bottle necks in the business commitment. Losses due to power enlarges amount to 10 percent of sales and production loss while in transit is 4 per cent of sales. In comparison with other like countries firms in Nigeria face higher indirect costs than firms in other countries.

Such countries lack in properly developed means of transport and communications, cheap and regular power supply, availability of sufficient raw materials, trained labour, well-developed capital and money markets etc.

Entrepreneurship is hindered by technological backwardness in less developed countries. This reduces outputs per man and the products are of substandard quality. Such countries do not possess the technical knew-how and capital to evolve their own techniques which may be output-increasing and labour absorbing mostly, they have to depend upon imported capital-intensive techniques which do not fit in their factor endowments.

Besides, as revealed by Hoselitz, a number of economic, social and administrative resistances face people in such economies to give preference to automated techniques over output-increasing techniques, Hoselitz [13] EDCC January (410) so far as the Schumpeteman process of innovation is concerned, Professor Hanry Wallich opines that "one can hardly say that in less developed countries 'innovation' is its most characteristic feature. The process is better described perhaps as one of assimilation. No one would deny, of course, to organize a new industry in a less developed country is an art of entrepreneurial initiative. But it is evidentially very different from the original process of innovation. Thus, the entrepreneur plays a secondary role in less developed countries due to various economic, social and administrative obstacles noted above.

The main problem in Less Developed Countries is to create a climate for entrepreneurship. The creation of such a climate depends on the one hand, on establishing social institutions which make possible objectively the exercise of independent individual enterprises, and on the other, on the maturation and development of personalities whose dominant orientation is in the direction of productivity, working and creative integration Hoselitz.

The realization of the first condition depends on a series of political acts which include the modification of the social institutions, the protection of property rights efficiently and the maintenance of law and order within the country. Besides, it requires the establishment of financial institutions which collect savings and canalize them for entrepreneurial activities. To facilitate this process, such financial institutions like the saving banks, investment banks and the complex of brokers, dealers and commercial banks that comprise the capital and money markets are required. The government should adopt such monetary and fiscal policies which encourage the growth of entrepreneurship. The shortage of skilled personnel of various kinds such as workers, scientists, technicians, managers, administrators etc. poses a serious problem in the success of entrepreneurship in L. D. Cs. It necessitates the setting up of scientific, technological, managerial, research and training and entrepreneurship development institute in every LDC as has been done in India in 1983.

These invariably have profound effect on motivation and attitudes towards work, towards organization and toward cooperative behaviour.
- The problem of Tribalism Versus Nationalism Nigeria as a nation in 1983 started to develop a new consciousness for national identity Hitherto, most Nigerian over played their ethnic and tribal loyalties when it comes to the question of hiring promotion and delivery of services. These deeply rooted ethical loyalties, create a major problem of nepotism in all its forms.

- Respect for Age and Seniority Orientation Nigeria is a seniority conscious society. There is an over-dependence on seniority and age even at the places of work. The general pressures are to place premium on seniority, the status of an officer and date of appointment are usually most important in consideration for promotion than demonstrated efficiency even the order in which a person's name comes on the staff list is jealously guarded and watched because this tends to be a critical factor when consideration for promotion comes up. This deep seated observance of seniority rule conflicts with the nation of selection and promotion by merit. It has an undesirable effect on moral and technical efficiency.

- The concept of time. There is the Nigerian time. This concept implies that time is not important Nigerians are not conscious of time. As long as Nigerians are not time conscious, they cannot be expected to be result-oriented.

- Bribery and corruption. The problem of bribery and corruption is widespread in Nigeria. It is a tradition too often tolerated by average citizens of supplementing low government pay with gifts and bribe in order to expedite routine processes. The problem of bribery and corruption is not peculiar to Nigeria but exists in all secretes to a greater or less extent. It is generally argued that SMEs have certain deficiencies because of intangible assets that drive their competitiveness in marketing, management of production, innovation and information technology. Among the support institutions, business advisory, counseling and information centres have proved to be particularly effective instruments for assisting entrepreneurs in starting and businesses, strengthening existing enterprises and helping their survival during the start-up period.

If such business centre made up of professionals had been established under the presidency it would addressed recurring problems of SMEs. In 200 or earlier Ogunleye [14] lists them as noted by Vision 2010 committee as fellows:

- Poor access to credit and other financial support or incentives

- Poor public sector support and policy inconsistency

- Poor account keeping habits, weak financial planning

- Poor infrastructure which significantly increases the cost of doing business

- Inability to hire highly skilled personnel

- Inadequate or lack of research

- Poor linkages among vibrant SMEs, large-scale enterprises and the rest of the domestic sector of the economy generally.

Policy incentives are tilted in favour of large scale industries: These were listed by Vision 2020 before the year 2000 Ogunleye reported them in 2000 . The missing like is the authority which has the responsibility to address and adequately solve them. The Nigeria government is concerned with the politics of Revenue Allocation and it 
has a stunted political context. Vision 2020 is committee evaluating the possibility of uplifting the Nigeria economy as the 20th largest economy in the world. The problems will continue to recur without attention and action directed at their solution. No organ or body is being blamed for this inaction not even the government that is preoccupied with its self inflicted failures. The obvious gap in government measures of creating a verile SMEs capable of sustainable growth is the ABSENCE OF BUSINESS SERVICE CENTRE.

\section{Business Services}

Business services help the SME sector realize its potential contribution to innovation and growth. Some of the most dynamic SMEs use business services to perform functions that cannot be undertaken in-house. A greater use of these services by a wider range of SMEs helps them to cope with the pressure of internalization.

Government of advanced market economies orient their policies and programmes towards fostering entrepreneurship. How? They are mounting specialized services and action plans to address these needs. For example: In the European Union (like African Union) the Business Environment Simplification Taskforce (BEST) is charged with simplifying the business environment for small firms in Europe. In the United States, the Small Business Administration (SBA) established in 1953, has long been the principal instrument for the design and implementation of policies for small business. SBA provides the startup design practically adjust its flarible structure in line with its locality and situational market to ensure the production of - value in the quality of goods and services at affordable prizes to meet the current tastes of its domestic customers, SBA notes the potential of the firm in terms of strengths and weakness. It will recommend it for government contract or assistance on the basis of realistic assessment of its specialty. It will rely on SBA to handle functions that cannot be undertaken in-house. This design, on the aggregate, affords SBA the unique role of having a comprehensive list of all small firms in the United States approved by law as well as their relative capabilities and specialties.

Not minding the BEST is there for all Europe, the United Kingdom still set up the Small Business Service (SBS) to not as a voice for small firms and to improve the quality of business support.

\section{Advantages of business services}

The guidelines on Best Practice on Business Advisory, Counselling and Information Services allows the reader on Entrepreneurs to get an overview of the policies and activities of central, regional and local governments. Secondly, the SME-support institutions, research and development organizations both in transition and advanced marked economies dealing with these issues in their countries. Thirdly, the aim of these Guidelines will strategically help firms. For example: It describes:

- experiences gained in creating and operating business support service institutions in UNECE member states. In Nigeria neither the government or any established body of government has responsibility to analyze these proven experiences and adapt their lessens to Nigerian environment for the benefit of it unknown tribal firms.

- How to create and operate successful business advisory, counselling and information services. The education and experience of officials of government or members and committees of the National Assembly are not wide and deep to delve into such international complexities. Even the administrative government officials must observe the line and staff rule of the limitation of staff economy in advising the line politicians who exercise authority.

- How to ensure the sustainability of such institutions. Nigeria needs only political sustainability by choosing from the already chosen. Secondly, political intervention dominates every sphere of development in Nigeria. Thirdly, the government is a symbol of people who are indifferent and suspicious of government programmes and survival of Nigeria is not depended on effort and contribution of its government but on Revenue from crude oil tax. Nigeria's fiscal policy is section 308 of its constitution which legitimizes the management as done by government in their official capacity.

The army generals took over the governance of Nigeria by fire of arms. The policy of governance is: What Exists is likely to be misallocated. In practice in Nigeria it was brazenly misallocated. They allocated the national oil blocks to themselves their relations and fronts by military Decrees.

\section{Definition and classification of business services}

Small firms have capability to be efficient, innovative and their ability to compete in the national market and internationally. If given business service support. To assist them, professional, technical and consultative services need to be provided through support systems and infrastructure.

The European Union defines Business Services as a group of different activities. The different functional characteristics of enterprises explain the number of these activities. Business Services include highly advanced consultancy services, professional services, marketing services, labour-intensive services and security services as well as human resources development and innovative policy focused on technology oriented SMEs.

The common policy Framework of the European Commission [15] states that the important contribution of Business Services to Industrial Performance and that the business services classification consists of 26 activities in 8546 - sectors. The activities are:

- $\quad$ Computer and related services

- Hardware consultancy

- Software consultancy

- Data processing

- $\quad$ Data base services

- Professional Services

- legal activities

- accounting

- $\quad$ tax consultancy

- $\quad$ management consulting

- $\quad$ Marketing services

- $\quad$ Market research

- Advertising

- Technical services

- $\quad$ architectural activities 
- $\quad$ engineering activities

- technical testing and analysis

- $\quad$ Renting and leasing services

- $\quad$ renting of transport and construction equipment

- $\quad$ renting of office machinery including computers

- $\quad$ Labour recruitment and provision of personnel

- Operational services

- Security activities

- Industrial cleansing

- $\quad$ Other services

- Secretarial assistance

- Translation activities

- Packaging activities

- $\quad$ Fairs and exhibition

\section{Core principles of Business Development Services}

The United Nations Conference on Trade and Development (UNCTAD) [16] sees the creation of the effective business development services which have their core principles as one of the most important tasks in developing SME.

Demand-side orientation and adaptation to users' needs: Instigation of dialogue with SMEs by customers and end users is extremely important. This will help SMEs identify their own needs as well as strengthen their links with local service providers and other support institution. The core principles include:

- $\quad$ Focused, strategic and collective approach: This principle insists on securing an extremely cost effective provision of some services to clusters of small businesses operating in close geographical proximity. This in addition, can provide unique opportunities for fostering or strengthening links between small enterprises them. This will enable them to enjoy economies of scale in their operations.

- Subsidiarity: Services must be brought as physically close to small-scale entrepreneurs as possible. Government institutions should make indirect use of local support structure. They are usually one-step centres sometimes specialized when entrepreneurs have access to a whole set of services needed to develop their businesses.

- Market oriented and business like: The participation of the private sector in offering SME services is now receiving more attention. The private sector includes trades or industry organizations, chamber of commerce business associations, semi-public institutions, private consultants and Non- Government Organizations.

- Cost Recovery: Business Development Services are expensive. In order to reach increasing levels of recovery, small businesses must improve profitability and productivity through their services which making willing to pay higher prices to access additional services.

- Gross-subsidization services and clients: Marketing technology, accounting and legal services have clearly proven their potential profitability or financial viability. Other services such as access to information and training are not as profitable because of 'free rider' effects or because the need is not clearly perceived. This means that the revenues earned by viable services may finance a number of complementary services, which are less viable but which are believed to have a beneficial impact on participating enterprises or on the market as a whole.

- Sustainability is only assured when the service provisions have reached a status (by regulation, state or other long-term budget provisions or commercial viability) when they can survive and develop without other external intervention. This requires that both the demand and the supply are monitored so that continuity of services is truly determined by real needs and delivery of services that truly and economically respond to those needs within the local blanket context. Experience in many countries shows that this may take longer than is often envisaged in the planning stages and is probably not achievable in a period of less than 10 years.

- Monitoring evaluation and performance indicators: Monitoring should cover the relevance and timeliness of services delivered and should be linked to regular evaluation of the direct and measurable impact on Business Development Services on the enterprises in terms of changes in productivity, profitability quality, sales and employment.

\section{Major findings}

- Reliance on the dead 'phase' provides government with huge idle fund which section 308 of 1999 CFRN empowers the President or Vice President, Governor or Deputy Governor to handle while in office either for public prosperity or personal prosperity of the incumbent.

- The low qualification of membership of the National Assembly in Section 65 of 1999 CFRN-"up to at least school certificate or its equivalent" make room for unclear law that protect political interests and reflect the values of corruption and enthrones illiteracy and detached populace.

\section{Conclusion}

The Nigerian government is the exact symbol of its people who are predominantly illiterate with low human capital and possessing unemployable skill. Nigeria and Nigerians behave the way they like their survival is dependent on their effort but on oil and gas revenue. The politics of Government Budgeting is settled on gaining greater share in the Revenue Allocation Formular. Some officials are empowered constitutionally to live above the Rule of Law in their official capacities. This enthrones bribery and corruption misgovernance and self-inflicted failures on the nation.

\section{Recommendations}

- The Dead phrase AS AND WHEN PRACTIBLE showed be removed or expunged from the Nigerian constitution to enable Nigerians enjoy free education at all levels and produce prepared and ready entrepreneurs for maximum use of Nigeria's endowment.

- The educational standard -up to at least school certificate or its equivalent is a blind beginning in this era of globalization.

\section{References}

1. Ezekwesili O (2013) The Wealth and poverty of a Nation, who shall restore the Dignity of Nigeria? NSUKKA: University of Nigeria, I press Ltd.

2. Anya OA (2003) Empowering Small and Medium Scale Enterprises in Nigeria Enugu: CIDAP PRINTING PRESS. 
Citation: Nnadi C (2014) Entrepreneurship Development and its Impact on Small Scale Business Enterprises in Developing Countries: A Nigerian Experience. J Entrepren Organiz Manag 3: 119 doi: 10.4172/2169-026X.1000119

Page 8 of 8

3. The Economic Commission for Europe (ECE) (2002) BEST PRACTICE IN BUSINESS ADVISORY COUNSELLING AND INFORMATION SERVICES NEW YORK: UNITED NATIONS.

4. UNECE (2003) in Economic Commission for Europe.

5. Nicholson-Herbert S, Mkhize S, Schroder A (2004) Turning Managers into Leaders, A South African Perspective on Corporative Entrepreneurship ESADE MBA BUSINESS REVIEW.

6. Onah FE (2004) The Impact of Economic Globalization on Nigeria's Industrial Sector. Nigerian Journal of Social Sciences 4:1.

7. Federal Republic of Nigeria (2004) Obasanjo's Economic Direction 1999-2003 Ikeja: Dawn Functions Nigeria Limited.

8. Carlyle in Purver, Tinsley MJ, Tarber JE, Bjorklund CC (1983) BUSINESS LAW Text and Cases Washington: Harcourt, Brace Jovanovich Inc.

9. Koentz MO, O'Donnell C, Weihrich H (1980) MANAGEMENT, McGraw-Hill International Book Company, London.
10. Covey SR (2004) The Habits of Highly Effective People Powerful Lessons in Personal change, New York.

11. Harbison FH (1973) Human Resources as the Wealth of Nations, Oxford University Press, London.

12. Drucker PF (1979) The practice of Management London: Convage Place.

13. Hoselitz BF (1954) The Early History of Entrepreneurial Theory Exploration in Entrepreneurial History.

14. Ogunleye GA (2000) Small and Medium Enterprises as Foundation for Rapid Economic Development in Nigeria Abuja: NDIC QUATERLY.

15. Common Policy Framework of European Commission in Economic Commission for Europe (2002) Best Practice in Business Advisory, Counseling and Information Services New York: United Nations.

16. UNCTAD in European Commission for Europe 2002. 